\title{
Formative Value of an Active Learning Strategy: Technology Based Think-Pair-Share in an EFL Writing Classroom
}

\author{
Cavide Demirci ${ }^{1, *} \&$ Halil Düzenli ${ }^{2}$ \\ ${ }^{1}$ Faculty of Education, Eskisehir Osmangazi University, Eskisehir, Turkey \\ ${ }^{2}$ School of Foreign Languages, Anadolu University, Eskişehir, Turkey \\ *Correspondence: Egitim Fakültesi, Eskisehir Osmangazi Universitesi, Eskisehir, Türkiye. Tel: 90-222-239 \\ 3750-1654. E-mail: demircicav@gmail.com
}

Received: November 17, 2017

Accepted: December 8, 2017 Online Published: December 15, 2017

doi:10.5430/wje.v7n6p63

URL: https://doi.org/10.5430/wje.v7n6p63

\begin{abstract}
Think-Pair-Share (TPS) activities in classrooms provide an opportunity for students to revise, practice and reproduce previously learned knowledge. Teachers also benefit from this active learning strategy by exploiting new learning materials, saving time by minimizing presentations and using it as a formative assessment tool. This article explores how a teacher can employ the strategy to both promote active learning and conduct formative assessment in a time-efficient way. To do this, a TPS activity was designed on an online platform along with an assessment rubric for student products. In 60 minutes, students thought individually on the topic provided, discussed and collaborated in groups and finally wrote down their paragraphs on the online tool. Each group shared paragraphs simultaneously. The teacher examined the paragraphs in terms of the predefined learning outcomes and determined the points to be revised. The students answered an open-ended online questionnaire a day later and the qualitative data were analyzed through a coding system. The assessment results successfully showed the learning points to be revisited and the results of the questionnaire supported the assessments of the teacher. The majority of the students revealed that they were satisfied and willing to do the activity again in the future.
\end{abstract}

Keywords: active learning; formative assesment; EFL written products

\section{Introduction}

In the field of education, active learning is a commonly understood term without further need for an explanation. The term was introduced into the literature by R. W. Revans (1907-2003) (Weltman, 2017). Scheyyens et al. (2008) state that active learning could be best defined by saying what it is not: "active learning is not an approach in which learners sit and listen to the teacher in a passive mode." In active learning, a higher importance is attached to improving the skills of the learners than transferring information. Learners are directed to a higher thinking level (such as analysis, synthesis and evaluation) and encouraged to develop their own attitudes and skills as they actively participate in the activities (Bonwell and Eison, 1991). Teachers are presented with the opportunity to establish unconventional, creative and enjoyable learning environments thanks to active learning strategies. Active learning is closely related to learning approaches and theories such as the constructivism and discovery learning. Active learning is a student's active impact on learning and a student's involvement in the learning process which allows students to focus on creating knowledge with an emphasis on skills such as analytical thinking, problem-solving and meta-cognitive activities that develop students' thinking (Niemi, 2002; Rotgans and Schmidt, 2011; Niemi and Nevgi, 2014). Bates and Townsend (2007) noted that the transformation of schools depends on the transformation of teachers. All learning activities are active in some sense, but active learning refers to the level of engagement of the student in the instructional process. Surprisingly teachers' use of the term "active learning" is based on intuitive agreement rather than common definition (Bellanca, 2008). Active learning is a dynamic type of learning where students intensely interact with each other, with education materials, and with teachers (Demirci, 2017).

Active learning encompasses a number of strategies and is open to development. Some of the widely used active learning strategies are: making presentations and having debates, role-play, teaching through games, field trips, group or class discussions, and keeping journals (Silberman, 1996). In addition to these, many strategies that could 
be used to start, proceed and end a lesson can be implemented as activities in active learning (Demirci, 2006). These strategies are: Determining what is known and what is to be known, invitation to share a new event, motivating questions, homework, opinion and feeling cards, fast and quick progress, gradual and layered teaching, conclusion sentence, voting, think-pair-share, talk or pass, writing an answer to a question, write-share-learn and asking a friend (Demirci, 2003).

Teachers should use any of the strategies above they think suitable for their students, the subject, and the level of the class. They should immediately change the strategy when they see it is not effective (Demirci, 2006). The students are expected to cooperatively discuss the learning material, take part in the process, and to demonstrate their learning by creating products like short written works at the end of the process (Bonwell and Eison, 1991). Many new and strategies with a potential to provide students with innovative and unique experiences for the students could be developed thanks to the constant advance of new technologies.

\subsection{The Think-Pair-Share Strategy}

The Think-Pair-Share (TPS) Strategy is one of the activities that can enable active learning in class. In this activity, students think about a question or problem individually, then discuss their thoughts with a peer or in a group, and finally present the class the thoughts that they have formed as a pair or a group (McTighe and Lyman, 1988). This technique has been proven many times to facilitate more profound and meaningful learning (Prahl, 2017; Bamiro, 2015; Kothiyal et. al., 2013). TPS requires students to think about the lesson content as it spreads the benefits of small group cooperative learning processes to the whole class. Throughout this process, students make preparations by using high level thinking skills and contemplating on how they will discuss and present their opinions. Another advantage of this technique is that it functions as a formative assessment tool for both the student and the teacher. Feedback from both the teacher and the pairs as well as feedback resulting from their own thinking process provide the students with a chance to assess their own learning. Moreover, the (written or oral) products at the end of the process could provide both the students and the teacher information about the learning levels of the students (Robison D. F., 2006; Black P. \& William D., 1998).

Prahl (2017) points out that the most important point to consider in this activity, which is seemingly easy to implement in classroom, is the quality of the initial question or problem that will navigate the whole activity. About the features of the question or the problem Prahl concludes:

a. Learning outcomes need to be considered when writing the question or the problem.

b. The question in the activity should be equivalent with the assessment question or problem for an evaluation of the learning as a result of this activity.

c. Open-ended questions with multiple possible answers should be formed.

d. The focus should not only be on the answers but also on how these answers have been formed.

e. Questions should be formed in a way that they support collaborative learning and that they encourage students to focus on others' opinions.

f. In designing questions it is important to encourage discovery and research.

It is quite natural for the features of the field of subject to shape the question or the problem that will navigate the activity in the designing process. A question or the problem prepared for a history class will differ from the question or the problem prepared for a language class in terms of its features. The questions to be asked should also be shaped by the targeted level of knowledge in the field of subject (McTighe \& Lyman, 1988). The situation could be perceived slightly differently for language teaching. English learning has its own classification of skills, and the learning outcomes for each skill are usage-based both receptively and productively (Pearson Education, 2016). Target structures to be learned in grammar teaching are learned in the dimensions of form, meaning, and use. Accordingly, the question prepared for a Think-Pair-Share activity to be used in an English grammar class should aim the usage of the given structure by keeping the learning outcomes in mind.

A TPS activity could be carried out in different classes and environments. This type of activity, which allows the integration of technology, has been executed over Google Docs by Slone and Mitchell (2014) in a Biology class, and following a discussion session, the students recorded their answers on a shared online document that could be seen by all the students. As opposed to the traditional TPS, the "share" phase was online and simultaneous, and all the students were able to see and examine the works of other students.

In this study, a TPS activity was done over Google Docs Web Tool in an intermediate-level Basic English class in the context of "future tenses and expressions for prediction," in line with the learning outcomes and target structures 
below:

Table 1. Learning Outcomes and Target Structures of the Activity

\begin{tabular}{ll}
\hline Learning Outcomes & Target Structures \\
\hline $\begin{array}{l}\text { Can use time expressions to make predictions for the } \\
\text { future. }\end{array}$ & Future time markers (near future) (distant future) \\
$\begin{array}{ll}\text { Can use future time structures to make predictions for } \\
\text { the future. }\end{array}$ & Future Tenses (will, be going to) \\
& Future Expressions (Probably- likely- unlikely) \\
& Future Modals (May-Might-Could) \\
\hline
\end{tabular}

The aims of the study are to:

1. determine the formative value of the TPS activity by looking at the students' work

2. evaluate the effectiveness of the technology-based implementation of the TPS activity in the light of the students' opinions.

\subsection{Implementation of the Activity}

The activity has been conducted with 18 students attending an intermediate class (with a total number of 22) in the English Preparatory Program of School of Foreign Languages at Anadolu University. The English Preparatory Program implements an integrated EFL curriculum and aims to prepare the students for communicating in English in their departments. The subject of "future tenses and expressions for prediction" was taught in the given class approximately two weeks prior to the activity within a unit (Clare, A. \& Wilson, J. J., 2011) with the theme of "future," and the students went through several practice and production phases.

Before the activity, the question required for the TPS was prepared, for which the principles put forward by Prahl (2017) were taken into account. In addition to these principles, 4 sub-topics were added to the question in order not to render it neither too wide, which would distract the discussion nor too narrow, which again would confine it. Thus, the question was formed as follows:

"As a futurist, what is your view of the future?

Topics: communication, transportation, food, health."

The students were expected to use the target structures aiming at the outcomes (Table 1) related to the topic.

Although the registered number of students was 22, it was expected the day before the activity that the appropriate number of the groups in class would be 4, taking into consideration that there are 2 drop-outs and diversity of students attending the class (between 16-20) on a daily basis. A Google Docs file to serve all four groups was created and uploaded onto the teacher's account. In order for the groups to locate their individual slot and not to write on other groups' slots, every slot was colored differently. Also, four of the students in possession of a laptop computer were asked to bring them along for the next day. The teacher took the e-mail addresses of the same students so as to share the activity link with them on the day of the activity.

The Google Docs file that had been created prior to the lesson was shared on the day of the activity with the students who had given the teacher their e-mail addresses. The aim and procedure of the activity was explained to the students. They faced no difficulties, as it was a strategy they had used before.

\subsubsection{The "Think" Stage}

As a lead-in, the teacher asked the students whether they knew Michio Khaku, a famous theoretical physicist also known for his predictions about the future. The information about the scientist along with examples of his predictions was shared with the students. The aim at this step was to prepare students by activating their prior knowledge and attracting their attention. Following this step, the question to be asked to the students was orally presented and the students were asked to think of answers. No particular amount of time was allocated to this part, which lasted approximately 10 minutes under the monitoring of the teacher. Throughout this period, the students were allowed to use their mobile phones and do small-scale online research about the subject.

\subsubsection{The "Pair and Share" Stages}

In this stage the students were divided into four groups. A student with a computer was put in each group, and the other members were selected by the teacher. The teacher did not assign particular students to the same group with the knowledge that they may negatively affect each other. The desks were adjusted in a fashion that would allow the 
students in one group to work on one computer screen. The members of each group were allowed to decide on the student to type for the group, with the exception of one student, who was assigned upon consent to this task by the teacher on accounts of his apparent reluctance. After the groups were formed physically (approximately 5 minutes), the students were asked to open the file on their computers and form their writing as they discussed. Pair and share stages were conducted simultaneously in this part. The students were able to create their texts while they also followed the development of the other groups' work on screen throughout this part, which lasted for about 30 minutes. By the end of the process four different paragraphs on the same subjects had been formed on the same document. 10 minutes of extra time was given to the students to examine the work of other students after they finished theirs. In this way, they had extra time for the share stage. The texts created by the groups are given below.

Table 2. The Products of Group Work

GROUP 1 - As a futurist, What is your view of the future?

Topics :

Communication - Transportation - Food - Health

Technology is part of our lives.In the future, technology will develop like people.First of all communication will be easier than today. For near future, people can call each other with small watches and it will improve itself from day to day.If we think far future, people can call each other with hologram technology from their i-watches. Other important thing is transportation because of the fact that human population will be too crowded and it will provide to want better transportation.In the near future, transportation will be improve itself with underground transportation and air transportation. There will be flying cars and faster underground transportation system. Other thing is food. In the near future, people can eat powders of protein, carbohydrate, oil. In the far future, people can feed themselves with electricity energy and wind energy. Last important thing is health. In near future, people can cure themselves with nano technology and far future they will turn into cyborg and they will not have any health problems. In brief, technology will make our life easy.

GROUP 2 - As a futurist, What is your view of the future?

Topics :

Communication - Transportation - Food - Health

\section{THE FUTURE}

In the future, we think that a lot of things will be changed. We will talk about communication, transportation, foods and health. Firstly, we think that we will be able to speak with power of thinking and it will be with a chip on our nape. At the same time, we will be able to speak different languages with the chip. Secondly, there will be flying cars in our life in the future. So we will travel easier than now and there won't be any traffic problems because the flying car will be controled by the computers. Another thing is that there won't be solid foods and we can drink every foods as a liquid in the future. This will save our time. Lastly, medicine will be developed a lot and there will be a machine which check our health problems when we enter the capsule cure us. To sum up, the future will come with a lot of benefit things.

GROUP 3 - As a futurist, What is your view of the future?

Topics :

Communication - Transportation - Food - Health 


\section{A BETTER WORLD?}

In the near future, technology will evolve, because of that people consume the technology quickly. Therefore developing of the technology will stop. In the far future, people will be lazy, so people won't produce anything. We may be able to communicate in any language which we choose. Headphones are working on translating machines that use the voice frequencies of the speaker, in the near future. In the far future, people will mind reading, but they can't read all things inside the mind. They can only see the thoughts that we want. In this way communication will be easier. The near future of transportation will not develope much. Companies of car may invent the specific car which works with solar energy and electricity, because people realised that source of natural will decrease in the our lives. In the far future, people can teleport anywhere they want. In this way, they don't need vehicles. In the near future, people will innovate fridge. This fridge make meal. People just put food materials in fridge. Fridge combine food and make meat. In this way, people want spend time for meal. In the far future, foods aren't problem for people, because foods seem like pills. In the near future, stem cells will become widespread. In the long term, there is hope that 3D printers will make copies of body parts such as hearts, livers and kidneys.

GROUP 4 - As a futurist, What is your view of the future?

Topics :

Communication - Transportation - Food - Health

Our lifes changes quickly from day to day because of technology. Everyday we learn new things and we renew. When we think our lifes, in the future, everything will be different. Firstly, people won't need to speak. They will communicate thanks to telephaty. In our opinion, it won't be good for mankind because after a while people will lose their speaking skills. Also, if people know all ideas about them, the world won't be a place to live. Secondly, transportation with vehicles will be end. Teleportation will solve all transportation problems. It will be fast more than now. You will reach all around the world in minutes. Moreover, people will be fed with pills. In the future, there will be pill machines and when you choose your meal, machines will give you it as a pill. However, It won't give a happiness like eating food. Furthermore, there will be big a development about health. There will be a machine and this invention will destroy some occupations like doctors. This machine will provide get rid of all ilnesses. In conclusion, technologhy tries to make our lifes easier but it has got lots of disadvantages. In the long term, mankind will take after robots.

The activity took 55 minutes in total. Also the link to the Google Docs file was posted on the Edmodo platform of the class for further access by all the students.

\section{Method}

This study is an exploratory case study (Lune \& Berg, 2015). Sample case studies are based on the study and evaluation of a case in its own context. In research, case studies are used to: a) define and see the details that form a case, b) develop possible explanations related to a case, and c) evaluate a case (Büyüköztürk, 2014). Discovery case studies can also include a pre-designed study or the study of an organization designed for a study (Lune \& Berg, 2015). In this study, the case is the implementation of a teaching design including student participation, which can be a solution to the ineffective and poor teaching design process. This model was selected since the aim was to evaluate the practice in its own context. Qualitative data collection and analysis techniques were used in the scope of the model. Information about the participators, data collection tools, and data analysis are given below.

\subsection{Participants}

The study has been conducted with 18 intermediate level basic English students attending the same class. 17 out of 18 students answered the questionnaire that was given one day after the activity. The students' ages differ between 18 and 21. Two different groups of data have been collected in line with two subordinate outcomes with an end to reach the aims of the study. The data source was the 4 paragraphs created by the students in the former, and the opinions of the students in the latter. 


\subsection{Data Collection Tools and the Data Analysis}

\subsubsection{Student Works}

The rubric-based assessment, which is quite a common way of assessing written works, has been used to assess the products of this activity. The rubrics used for the assessment of written works after the TPS activity are prepared according to the answers given to the question designed for the teaching subject, whether the key concepts have been used, and the accuracy of their use (Prahl, 2017). The works gathered after the activity were assessed with a rubric (Table 3) developed by the writer and studied for their formative value.

Table 3. The Rubric Used for the Assessment of the Works

\begin{tabular}{|c|c|c|c|c|}
\hline \multicolumn{5}{|c|}{ TPS Activity Paragraph Assessment Rubric) } \\
\hline Target Structures & Used (x2) & Used Correctly (x2) & Score & Teacher's Notes \\
\hline \multicolumn{5}{|l|}{ Future Tenses (will) } \\
\hline \multicolumn{5}{|c|}{ Future Tenses (be going to) } \\
\hline \multicolumn{5}{|c|}{ Future Expressions (Probably- } \\
\hline \multicolumn{5}{|c|}{ likely-unlikely) } \\
\hline Total & & & & \\
\hline
\end{tabular}

Student products on the rubric were scored according to:

1. whether the student used the target structure

2. whether the student used the target structure correctly

The range and accuracy of the target structure use has been considered as having superior importance to the score value of the results.

\subsubsection{Open-ended Questioannaire}

An open-ended online questionnaire consisting of 5 questions was given to the students in the Lab class on the following day. The questions are:

1. What do you think about the organization of the activity (timing, groups, teacher's role, etc.)?

2. What do you think about the web tool (Google Docs) used for the activity (attractiveness, usability, hardware, etc.)?

3. What do you think about the interaction within the group (student roles, discussion, production, contribution, etc.)?

4. How did this activity help you see your strengths and weaknesses in the subject (future time)?

5. If you were to compare this activity with the pop quizzes implemented regularly, which one would you think helped you to a better extend see your strengths and weaknesses in the subject? Why?

The answers given to the questionnaire have been coded with themes formed for each question and analyzed using descriptive analysis, which is a qualitative analysis method. The themes, subordinate themes and the coding scheme used in the data analysis are given below.

Table 4. Open-Ended Student Questionnaire Form Themes and Coding Scheme

\begin{tabular}{|c|c|c|c|c|}
\hline Themes & Sub-themes & Value & CODE & Sample Data and CODE \\
\hline \multirow[t]{3}{*}{ Organization } & Time & Enough/Not Enough & $\mathrm{E} / \mathrm{NE}$ & "Time given was enough." =YT \\
\hline & Teacher's role & Enough/Not Enough & $\mathrm{E} / \mathrm{NE}$ & $\begin{array}{l}\text { "The teacher helped when we } \\
\text { did not understand." =YT }\end{array}$ \\
\hline & $\begin{array}{l}\text { Groups and number } \\
\text { of members }\end{array}$ & Positive/Negative & $\mathrm{PS} / \mathrm{NG}$ & $\begin{array}{l}\text { "The groups were evenly } \\
\text { distributed." OL }\end{array}$ \\
\hline \multirow[t]{2}{*}{ Web Tool } & Attractiveness & Enough/Not Enough & $\mathrm{E} / \mathrm{NE}$ & $\begin{array}{l}\text { "Was not very attractive but it } \\
\text { did the job" }=\mathrm{YZ}\end{array}$ \\
\hline & Usability & Enough/Not Enough & $\mathrm{E} / \mathrm{NE}$ & "It was easy to use, we did not \\
\hline
\end{tabular}




\begin{tabular}{|c|c|c|c|c|}
\hline & & & & $\begin{array}{l}\text { have difficulty using the } \\
\text { program." YT }\end{array}$ \\
\hline & Simultaneity & Positive/Negative & $\mathrm{PS} / \mathrm{NG}$ & $\begin{array}{l}\text { "It was bad seeing what the } \\
\text { other groups were writing; the } \\
\text { groups tended to imitate each } \\
\text { other and drift away from } \\
\text { originality" =OZ }\end{array}$ \\
\hline \multirow[t]{2}{*}{$\begin{array}{l}\text { Interaction within } \\
\text { the group }\end{array}$} & Collaboration & Positive/Negative & $\mathrm{PS} / \mathrm{NG}$ & $\begin{array}{l}\text { "Someone from the group } \\
\text { certainly corrects your mistake." } \\
=\text { OL }\end{array}$ \\
\hline & Contribution & Balanced/Unbalanced & $\mathrm{B} / \mathrm{UB}$ & $\begin{array}{l}\text { "We were a very good team with } \\
\text { my group because some of us } \\
\text { came up with ideas and others } \\
\text { helped make sentences while } \\
\text { one group member wrote down } \\
\text { what was being said quickly and } \\
\text { correctly." =DN }\end{array}$ \\
\hline Formative Value & & Positive/Negative & $\mathrm{PS} / \mathrm{NG}$ & $\begin{array}{l}\text { "It showed me that I had to work } \\
\text { more on tenses." =OL }\end{array}$ \\
\hline $\begin{array}{l}\text { Comparative } \\
\text { Formative Value }\end{array}$ & $\begin{array}{l}\text { TPS Activity } \\
\text { Pop Quizzes }\end{array}$ & $\begin{array}{l}\text { TPS Activity/Pop } \\
\text { Quizzes/Both }\end{array}$ & $\mathrm{T} / \mathrm{P} / \mathrm{TP}$ & $\begin{array}{l}\text { "They were both effective } \\
\text { activities, but I think the TPS } \\
\text { activity motivates more } \\
\text { contribution" =D }\end{array}$ \\
\hline
\end{tabular}

\section{Results}

The results of the assessment of the group works are shown in table 5 .

Table 5. TPS Activity Formative Product Assessment

\begin{tabular}{|c|c|c|c|c|c|c|c|c|c|}
\hline \multirow{2}{*}{ Target Structures } & \multicolumn{2}{|c|}{ GROUP 1} & \multicolumn{2}{|c|}{ GROUP 2} & \multicolumn{2}{|c|}{ GROUP 3} & \multicolumn{2}{|c|}{ GROUP 4} & \multirow{2}{*}{ SCORE } \\
\hline & Used & Correct & Used & Correct & Used & Correct & Used & Correct & \\
\hline Future Tenses (will) & 2 & 2 & 2 & 2 & 2 & 2 & 2 & 2 & $16 / 16$ \\
\hline Future Tenses (be going to) & 0 & 0 & 0 & 0 & 0 & 0 & 0 & 0 & $0 / 16$ \\
\hline $\begin{array}{l}\text { Future Expressions } \\
\text { (Probably- likely-unlikely) }\end{array}$ & 0 & 0 & 0 & 0 & 0 & 0 & 0 & 0 & $0 / 16$ \\
\hline $\begin{array}{l}\text { Future Modals } \\
\text { (May-Might-could) }\end{array}$ & 2 & 2 & 1 & 1 & 2 & 2 & 1 & 1 & $12 / 16$ \\
\hline $\begin{array}{l}\text { Future time markers (near } \\
\text { future) }\end{array}$ & 1 & 1 & 0 & 0 & 1 & 1 & 0 & 0 & $4 / 16$ \\
\hline $\begin{array}{l}\text { Future time markers } \\
\text { (distant future) }\end{array}$ & 1 & 1 & 0 & 0 & 2 & 2 & 0 & 0 & $6 / 16$ \\
\hline
\end{tabular}

The results of the assessment show that the students used the target structures without making any errors when they used them. As for the range of use in their writings, it could be seen that they never used the structures of "be going to" and "probably-likely-unlikely." Similarly, out of the near and distant future expressions, they used the expressions that they presumably had learned in class with lower frequency. It is evident from their future predictions that they prefer the modal "will."

Although this table does not give us a clue about to what extend they have learned the meaning and form of the structures that they did not use, it does clearly show that these structures have not been put into use yet. The implication of this result may be that the teacher may want to further revise these structures. The fact that they made no mistakes in the structures that they used with less frequency again shows that there is a need for revision in relation to the usage. When everything above is taken into consideration, it might be a good idea for the class to take 
shape in the following days in accordance with "range in use" type of activities in the relevant subject aiming especially at the structures the students never used. These activities can be prepared in the form of paraphrasing activities, which provide students with a chance to produce alternative structures.

The results of the open-ended student questionnaire are shown in Table 6.

Table 6. The Results of the Open-Ended Student Questionnaire

\begin{tabular}{|c|c|c|c|c|}
\hline Themes & Sub-Themes & Value & $\begin{array}{l}\text { Number of } \\
\text { people } \\
(n=17)\end{array}$ & f\% \\
\hline \multirow[t]{6}{*}{ Organization } & Duration & Enough & 10 & 59 \\
\hline & & Not enough & 1 & 6 \\
\hline & Teacher's role & Enough & 8 & 47 \\
\hline & & Not enough & 0 & 0 \\
\hline & Groups and Number of & Positive & 14 & 82 \\
\hline & Members & Negative & 0 & 0 \\
\hline \multirow[t]{6}{*}{ Web Tool } & Attractiveness & Enough & 9 & 53 \\
\hline & & Not enough & 1 & 6 \\
\hline & Usability & Enough & 15 & 88 \\
\hline & & Not enough & 0 & 0 \\
\hline & Simultaneity & Positive & 9 & 53 \\
\hline & & Negative & 3 & 18 \\
\hline \multirow[t]{4}{*}{ Interaction within the group } & Collaboration & Positive & 14 & 82 \\
\hline & & Negative & 0 & 0 \\
\hline & Contribution & Balanced & 15 & 88 \\
\hline & & Unbalanced & 2 & 12 \\
\hline \multirow[t]{2}{*}{ Formative Value } & & Positive & 16 & 94 \\
\hline & & Negative & 0 & 0 \\
\hline \multirow[t]{3}{*}{ Comparative Formative Value } & TPS Activity & TPS Activity & 10 & 59 \\
\hline & Pop Quizzes & Pop Quizzes & 2 & 12 \\
\hline & Both & Both & 3 & 18 \\
\hline
\end{tabular}

Student views pertaining to the organization and implementation of the activity have proven mostly positive. Positive remarks have been received from the students on the duration (55 minutes) of the activity, and most of the students have found the time allocated enough. Only one student has stated the opinion that the activity should be readjusted to fit into the regular class hour ( 45 minutes). The students were naturally distracted in the last ten minutes of the activity knowing the break time had arrived but were also willing to postpone their break to be able to finish the activity. On the other hand, another student stated that the duration should have been longer:

"... the duration was long enough to write but not long enough to read what our friends have written..."

This shows that the student considers not being able to read the other students' work as a drawback. The teacher's role in this process was purposefully confined to minimum intervention. The fact that the common digital file could be viewed on the classroom computer has rendered the close monitoring of the teacher unnecessary. The teacher monitored all the groups through their works on the digital file. In the monitoring process the teacher paid short visits to the groups that fell behind in order to help them as a facilitator only by asking questions to encourage them to diversify their thoughts. Minimum intervention by the teacher and a freer space for student activity has been welcome by all the students that stated opinion on this topic. Some sample remarks are as follows:

"Our teacher was good and helpful. I can't say more on this because it wasn't an activity fit for the teacher to be very active..."

"The role of the teacher was enough. He provided help when needed..."

The fact that the students have realized that the teacher should give students space in such a manner by taking a passive stance shows that they are aware of the nature of active learning activities. Ideal number of members (4-5) was used in the grouping phase of the activity. Also, no standard set of instructions relating to interaction or member roles were given to the students. Students have commented positively about the number of group members and their 
distribution as well. One out of a number of similar remarks is as follows:

"We chose our own group, and it was very good, so the interaction within the group was very good, which made our group productive..."

Neither the remark by this student, who states that forming their own groups has an impact on the group productivity, nor the similar remarks by other students connote any negativity whatsoever.

Student opinion about the web tool used (Google Docs), which is a file sharing and collaboration platform open to free use for all students with or without a Google account alike, has been positive for the most part. The students have stated that the tool was attractive, and it was especially enjoyable to simultaneously access other group's writings. To illustrate, some students have stated that the tool was easy to use and attractive at the same time by saying:

"... It is easy to use; you can exchange things comfortably..."

"... A very good application by Google. Very easy to understand..."

"... It's been a different practice, but it was a very good activity to have everyone in the same session simultaneously..."

It is also possible to conclude that some peer feedback/correction methods have been employed by looking at a comment by another student:

"... It was very useful; we were able to get help and were presented to different opinions by other groups in this way. We even corrected the texts of some other groups and dealt with wrong words without them noticing..."

Some students attracted attention to an issue about the commonly accessible web tool and its simultaneity:

"...It is an effective application as it enables us to freely revise the things we write. It is sufficiently designed, but it is not a good idea for the groups to see each other's work..."

"...The web tool used was quite attractive, but It was bad seeing what the other groups were writing; the groups tended to imitate each other and drift away from originality..."

"...I think everybody shouldn't see our opinions; they steal them..."

The simultaneity of the think and share stages enabled the groups to create their works and follow what the other groups were doing at the same time, but from the point of some students, this diverted the student opinion from originality and even created the feeling that some students were cheating. Students' works have been reexamined for any possible justification of this suspicion, but no traces of cheating or large-scale similarity has been detected. The teacher's personal observation during the activity further concludes that the groups experienced collaboration at a high level within the group and that they prioritized the opinions within their own groups instead of transferring the ideas of other groups even after they followed them throughout the process with curiosity. As for the hardware, one student commented that he attempted to access the file on a mobile phone and later on a tablet without success. It can be said that mobile-compatible web tools would be more usable and attractive for students, but PC use was thought to prove more advantageous in this writing activity, where keyboard use and fast modification were important aspects.

Practically all students made positive remarks about interaction and collaboration within the group. Especially concepts like exchange of opinions, collaboration and peer learning have found their place in the positive comments:

"...The interaction was very good. All the members worked with a smile on their face. We put forward different opinions and then we transferred them to our writing after organizing them. We had a lot of fun doing that, and the result was a beautiful piece of writing..."

"...group activities are always very effective. We exchange ideas as we see each other's mistakes and learn from each other..."

"... We were a very good team with my group because some of us came up with ideas and others helped make sentences while one group member wrote down what was being said quickly and correctly..."

"...This gives us the opportunity to learn by discussing. You do not forget what you have learned in a group after a discussion. Also, a member of the group certainly corrects what you've written, which allows you to see your mistake..."

The teacher detected only one reluctant student as the activity was about to start, upon which he was given the role of the facilitator. Another student from the group seems to have referred to this situation: 
"...although we weren't able to communicate well in the beginning, we were then able to do it under the leadership of our typing member..."

It is clear that assigning the reluctant student to the particular role has worked well and the student has performed the role of the facilitator by catalyzing communication within the group. A student from another group commented negatively about the interaction within the group:

"... Every member in our group expressed his or her opinion. We came up with a common decision after discussion and then wrote down our opinions. However, some of our friends could have participated more..."

It is natural for some students to be more active and productive in this kind of activities. Similarly, it is also possible for some students to remain passive. The teacher has not observed any students that have made no contribution at all.

Number 4 and 5 questions were designed to get opinions about the formative value of the activity. The relevant answers have shown that the students have benefited from the activity as it informed them about their learning. While the majority of the feedback from students only states that it helped them to see their strengths and weaknesses, some students have also elaborated on how it was able to do this:

"...my strength is that I can continuously generate ideas on the given topic; my weakness is that I keep using the same structures while making sentences. I realized these by experience during the activity..."

"...It showed me that I had to work more on tenses..."

The program in which the study was conducted uses standardized pop quizzes in all classes as a formative assessment tool. These quizzes largely assess structure and meaning on the level of recognition. Therefore, question types are mainly gap filling, matching, and multiple choice. When students were asked to compare these quizzes to the TPS activity in terms of their capacity to show them their strengths and weaknesses, a majority of the students stated that they found the TPS activity more effective. A sample comment reads:

"...I think this practice was more beneficial. Because the quizzes include no interaction, I immediately forget after I leave the class. However the things we discussed in the first class are still in my mind..."

It is important that the student has emphasized the value of permanence. It could also be said that this activity is better in terms of permanence when the formative and teaching value of assessment activities is taken into consideration. Nevertheless, some students have said that quizzes are more effective in seeing mistakes since they provide immediate feedback:

"...I usually realize my mistake in quizzes. We wrote what we can already write in the first class hour, but in quizzes I can better see the structures that I don't normally use..."

Similarly, some other students have stated that the works need to be given feedback in order to increase formative value of the activity:

"...This activity was way more useful. I think quizzes are not necessary. It would be better if we reviewed our sentences, read them to our friends and corrected our mistakes with the teacher instead..."

Taking into consideration the student who said he could not find the time to read his friends' writings and the students who emphasized the need for extra time for feedback, it can be concluded that the teacher might have conducted a short feedback session at the end of the activity, relying on the notes he might have taken during the monitoring.

\section{Discussion}

The students have realized for the most part that they experienced active learning. It has been shown that the development of high-level cognitive skills, which lies in the core of active learning, has been achieved through this activity. It can be said that the students also agree on the confined role of the teacher and collaboration and productivity within the group. Most of the comments pertaining to the activity showing the students' strengths and weaknesses with the target structures have also been positive. Student views converge in that the formative value of this type of active learning activities is higher when compared to that of the quizzes, which assess only structure and meaning and provide formative feedback on this level. As Eison, J. (2010) states in a study, the TPS activity has encouraged students to reflect on the content of the lesson as well as their own learning. Furthermore, the results of this study support the findings of the meta-analysis study by Freeman et al., which clearly show that the active learning approach increases academic success more than traditional teaching strategies. Although an academic success test has not been conducted in this study, student feedback and products indicate that they will be more 
successful in the context of the subject that is studied. In their study on active learning strategies in English classes, Amran et al. (2016) have found that students prefer group activities to individual ones and they would rather do these activities in technology-based environments or with such tools. This study has shown that a similar preference is evident among Turkish university students.

The product assessment has shown that the students used the target structures with accuracy. However, it is also evident that some structures were never preferred or remembered by the students. In this context it has been realized that there is a need on the part of students to do revision practice that focus on range. This is a conclusion pop quizzes would fail in rendering. The use of a rubric has clearly demonstrated which structures were not used, which has supplied accurate and valuable information for the design of future learning and teaching processes. There is a set of possible conclusions leaning onto the study of this practice:

1. The duration of the activity should be parallel with the class hour of the program. An extra time period should be allocated to the "share" stage at the end of the activity.

2. Precautions securing hardware should be taken prior to the activity, assignments should be done, and stand-by equipment should be kept ready.

3. The teacher should assign the facilitators and typers of the group, but the selection of the group members should be left to the natural flow of the classroom.

4. The teacher should intervene at the minimum level possible and take precautions in advance for the ones that fall behind or finish too early.

5. Precautions such as assignment of responsibility should be taken against passive or reluctant students.

6. There should certainly be a teacher-guided feedback session simultaneous with or following the "share" stage.

As a result, the technology-assisted application of the TPS, which is an active learning strategy, could result in an activity high in formative value as long as the question or the problem to navigate the activity is prepared in line with the learning outcomes of the lesson and the process is administered in a time-efficient way in compliance with the suggestions mentioned above. It seems possible that there will be an improvement in the learning experience, the students will have a chance to see their weaknesses and that they will deal with these on a permanent basis by the help of peer interaction. The results of this activity, which was implemented in an English class, could serve as a formative assessment alternative for the teachers of other disciplines.

\section{Acknowledgements}

We would like to thank the Educational Technology Team in Anadolu University School of Foregin Languages, Turkey for their support.

\section{References}

Amran, R., Yokoyama, F., \& Nishino, K. (2016). Development of active learning methods of English in Japanese high schools to support student activities in group discussions. Procedia Computer Science, 96, 1471-1478. https://doi.org/10.1016/j.procs.2016.08.193

Aydede, M. N., \& Matyar, F. (2009). Fen bilgisi öğretiminde aktif öğrenme yaklaşımının bilişsel düzeyde öğrenci başarısına etkisi. Türk Fen Eğitimi Dergisi, 6(1), 115-127.

Bamiro, A. O. (2015). Effects of guided discovery and think-pair-share strategies on secondary school students' achievement in chemistry. SAGE Open, 5(1), 1-7. https://doi.org/10.1177/2158244014564754

Bates, R. \& Townsend, T. (2007). The Future of teacher education: challenges and opportunities. In Townsend, T. \&Bates, R. (Eds.), Handbook of teacher education: globalization, standards and professionalism in times of change. P.O.Box 17, 3300 AADordrecht, the Netherlands.www.springer.com.

Bellanca, J. A. (2008). 200+ active learning strategies and projects for engaging students' multiple intelligences. (2nd ed.). California: Corwin Press

Black, P., \& Wiliam, D. (1998). Assessment and classroom learning. Assessment in Education: Principles, Policy \& Practice, 5(1), 7-74. https://doi.org/10.1080/0969595980050102

Bonwell, C. C., \& Eison, J. A. (1991). Active Learning: Creating Excitement in the Classroom. 1991 ASHE-ERIC 
Higher Education Reports. ERIC Clearinghouse on Higher Education, The George Washington University, One Dupont Circle, Suite 630, Washington, DC 20036-1183.

Büyüköztürk, Ş., Çakmak, E. K., Akgün, Ö. E., Karadeniz, Ş., \& Demirel, F. (2014). Bilimsel araştırma yöntemleri. Ankara: Pegem Akademi.

Clare, A., \& Wilson, J. J. (2011). Speakout: intermediate students' book with active book. Pearson.

Demirci, C. (2003). Etkin öğrenme yaklaşımının erişiye etkisi. Hacettepe Üniversitesi Eğitim Fakültesi Dergisi, 25(25).

Demirci, C. (2006). Fen bilgisi öğretiminde etkin öğrenme yaklaşımının bilgi düzeyi erişiye etkisi. Eğitim ve Bilim, 31(139).

Demirci, C. (2017). The Effect of Active Learning Approach on Attitudes of 7th Grade Students. International Journal of Instruction, 10(4), 129-144. https://doi.org/10.12973/iji.2017.1048a

Eison, J. (2010). Using active learning instructional strategies to create excitement and enhance learning. Jurnal Pendidikantentang Strategi Pembelajaran Aktif (Active Learning) Books, 2(1), 1-10.

Freeman, S., Eddy, S. L., McDonough, M., Smith, M. K., Okoroafor, N., Jordt, H., \& Wenderoth, M. P. (2014). Active learning increases student performance in science, engineering, and mathematics. Proceedings of the National Academy of Sciences, 111(23), 8410-8415. https://doi.org/10.1073/pnas.1319030111

Kothiyal, A., Majumdar, R., Murthy, S., \& Iyer, S. (2013). Effect of think-pair-share in a large CS1 class: 83\% sustained engagement. Paper presented at the ICER 2013 - Proceedings of the 2013 ACM Conference on International Computing Education Research, 137-144. https://doi.org/10.1145/2493394.2493408

Lune, H., \& Berg, B. L. (2016). Qualitative research methods for the social sciences. (Çev. H. Aydın). Pearson.

Lyman, F. (1987). Think-pair-share: An expanding teaching technique. Maa-Cie Cooperative News, 1(1), 1-2.

McTighe, J., \& Lyman, F. T. (1988). Cueing thinking in the classroom: The promise of theory-embedded tools. Educational Leadership, 45(7), 18-24.

Niemi, H. (2002). Active learning - a cultural change needed in teacher education and schools. Teaching and Teacher Education 18:763-780. http://dx.doi.org/10.1016/S0742-051X(02)00042-2

Niemi, H., \& Nevgi, A. (2014). Research studies and active learning promoting professional competences in Finnish teacher education, Teaching and Teacher Education, 43: 131-142. http://dx.doi.org/10.1016/j.tate.2014.07.006

Pearson Education. (2016). Global Scale of English Learning Objectives for Adult Learners. Retrieved 16.04.2017 from https://prodengcom.s3.amazonaws.com/GSE_LO_AdultLearners_0415.pdf\#public

Prahl, K. (2017). Best practices for the think-pair-share active-learning technique. American Biology Teacher, 79(1), 3-8. https://doi.org/10.1525/abt.2017.79.1.3

Robison, D. F. (2006). Active learning in a large enrollment introductory biology class: problem solving, formative feedback and teaching as learning. Phd dissertation, Brigham Young University, Provo.

Rotgans \& Schmidt Henk G. (2011). The role of teachers in facilitating situational interest in an active-learning classroom. Teaching and Teacher Education, 27, 37-42. http://dx.doi.org/10.1016/j.tate.2010.06.025

Scheyvens, R., Griffin, A. L., Jocoy, C. L., Liu, Y., \& Bradford, M. (2008). Experimenting with active learning in geography: Dispelling the myths that perpetuate resistance. Journal of Geography in Higher Education, 32(1), 51-69. https://doi.org/10.1080/03098260701731496

Silberman, M. (1996). Active learning: 101 strategies to teach any subject. Massachusetts: Allyn \& Bacon.

Slone, N. C., \& Mitchell, N. G. (2014). Technology-based adaptation of think-pair-share utilizing Google drive. Journal of teaching and Learning with Technology, 3, 102-104. https://doi.org/10.14434/jotlt.v3n1.4901

Weltman, D. (2007). A comparison of traditional and active learning methods: An empirical investigation utilizing a linear mixed model. The University of Texas at Arlington.

\section{Notes}

Note 1 . The student works were kept original with their language and design as produced during the activity. 